\title{
Effect of Some Pesticides, Sugarbeet Cultivars and Their Interaction on Population Density of Tortoise Beetle Cassida Vittata Vill and some Characters of Sugarbeet Cultivars at Nubaryia and Damanhour Region
}

\author{
Abo El-Ftooh A.A.; ${ }^{1}$ Gohar, I.M.A; ${ }^{1}$ M.
}

\section{ABSTRACT}

The present study was conducted at the experimental farm Nubariya Agricultural Research Station, West Nubariya and Damanhour (Hafs village), Al Behera Governorate during the two successive seasons, 2010/2011 and 2011/2012, to study the susceptibility of seven sugarbeet cultivars three multigerms and four monograms to infestation with tortoise, beetle Cassida vittata Vill, and their yield and quality characteristics. The seven sugarbeet cultivars (four monograms Helsinki, Ravel, MK2134 and Sible and three polyograms cultivars Oscar poly, Gazella and Lilly) used in this study. Besides the of the three pesticides (Radiant SC ${ }^{\odot} 12 \%$, Mospilan ${ }^{\odot} 20 \%$ SP and Dursban $^{\odot} \mathrm{H} 48 \%$ EC) for reducing population density of beetle. The population fluctuations of $C$.vittata (larvae and adults) numbers were increasing whenever plants became bigger. Combined analysis over seasons and location demonstrated that the Helsinki cultivar was more resistant to larvae and adults of C.vittata. But Sible cultivar was more sensitive to tortoise beetle C.vittata (51 larvae and adults /plants). The seven cultivars can be arranged cultivars ascending order at harvest crop, according to attract cultivars of tortoise beetle as follow: Helsinki, Mk 2134 , Gazella, Ravel, Lilly, Oscar poly, and Sibel (49.7, $49.8,50.3,50.8,51.3,52.4$ and 55.9 ), respectively. In addition, Helsinki cultivar was superior in most yield characteristics such as root, top, and sugar yields and of sucrose percentage. Radiant SC $\odot \mathbf{1 2 \%}$ exceed when spraying and interact with seven sugarbeet cultivars in all the studied traits except T.S.S. percentage. Radiant SC ${ }^{\circledR}$ $12 \%$ was more toxic against tortoise beetle, Cassida vittata Vill (Larvae and Adults) in two regions through two seasons.

Key words: Cassida vittata. Radiant $\mathrm{SC}^{\odot} 12 \%$. Mospilan $^{\odot} 20 \%$ SP. Dursban ${ }^{\odot}$ H $48 \%$ EC., Sugar beet cultivars, Helsinki, Mk 2134, Gazella, Ravel, Lilly, Oscar poly, Sibel

\section{INTRODUCTION}

Sugarbeet, Beta vulgaris L. is considered one of the most important crop that rank next to sugarcane in importance as sugar crop in Egypt and attribute $48.1 \%$ of sugar production (Annual Report of Sugar Crops Council, 2012). In Egypt, sugarbeet is cultivated in 153.8 thousand feddans with an average production of

\author{
S. Saleh ${ }^{2}$ and Mohamed, Kh. El-Sh ${ }^{3}$
}

20.6 tons per Fadden 2011/2012 seasons, Chawdhery (2012). While, cultivated area in Al Beheira governorate was 44.309 feddans produced 682,309 tons with an average of 15.4 tons / fed. The lower yield per feddan is one of the major problem of sugarbeet production in the Al Beheira governorate (Ministry of Agriculture -the Directorate of AgricultureManagement of sugar crops - Damanhour region- Al Beheira governorate). Sugarbeet plants attack by numerous insect species during growing season. Both tortoise beetle larvae and adults feed on the lower side of the sugarbeet leaves, where, they eat the lower epidermis and inner tissue, but the upper epidermis remains intact looking like a glass. In addition, adults feed on leaves tissue, causing regular circular holes (Abo El Ftooh, 1995). Tortoise beetle C. vittata cause economic loss in sugar yield. The tortoise beetle, $C$. vittata de Villers (Chrysomelidae-Coleoptera) is among the major insects that caused lot of damage to sugar beet crop (Bassyouny, 1993, Mesbah, 2007 and Abo El Ftooh et al 2007). In Egypt, the tortoise beetle C. vittata considered one of the most serious and abundant species causing damage in sugar beet plants Samy et al (1992) and Hatem et al (2012). Traditionally, chemical pesticides were used for controlling all insect pests attacking sugarbeet crop in Egypt. In order to minimize the quantitative of chemical pesticides used for crop protection within the frame of the strategies in integrated pest management (IPM), biological control, especially microbial control, of insect pests became an important in such strategies as an effective alternative. (El-Khouly, 1998; Mesbah et al 2004). Also resistant varieties against disease and pests are needed. Radiant features an innovative active ingredient called spinetoram, which delivers control of destructive insect pests in fruiting and leafy vegetables, cucurbits and legumes. Like disease, insects are important causal factors of biotic stress in crop plants. Insects attack all the crop plants and lead to considerable losses in yield as well as quality. Insect attack leads to various types of damages. There are two important methods of insect control, biological method and chemical method. The

\footnotetext{
${ }^{1}$ Sugar Crops diseases \& Pests, Department Sugar Crops Research Institute, Agricultural Research Center (ARC), 12619, Giza, Egypt ${ }^{2}$ Genetic and Breeding, Department, Sugar Croup Research Institute, Agriculture Research Center (ARC), 12619, Giza,, Egypt.

${ }^{3}$ Physiology and Chemistry, Department, Sugar Crops Research Institute, Agriculture Research Center (ARC), 12619, Giza,, Egypt. Received Febuary 14, 2013, Accepted March 30, 2013
} 
chemical method includes use of various chemical, insecticides. Use of insecticides has several disadvantages. It increases cost of cultivation, reduces population of predators and parasites of insect pests, leads to environmental pollution and development of pesticides resistant biotypes of insects. In biological method, insects are controlled in three ways, viz, 1) by the use of predators and parasites of insect pests. 2) by using botanical pesticides such as neem, Datura, Ipomea in the form of leaf extracts, and 3) use of resistant varieties. Thus, genetic resistance is the cheapest and the best method of insect control in crop plants. Genetic resistance refers to the ability of some genotypes to give higher yields of good quality than susceptible varieties at the same initial level of insect attack under similar environmental conditions Rossi (1999) and Ferry et al. (2006).

The main purpose of the current investigation is select the most suitable pesticides and cultivars resistant to contribute the integrated control operations and interaction with pesticides and their impact on crop characteristics. The large number of sugarbeet cultivars were sown in Egypt Which imported from different parts of the world . These cultivars have different yield characteristics and different sensitivity of tortoise beetle Cassida vittata. Therefore, this experiment was designing by planting seven cultivars of sugarbeet in two important regions of sugar beet cultivation to choose the most suitable cultivars for cultivation in these regions In addition, select the practices to improve sugarbeet yield characteristics and to minimize the infestation with the key sugarbeet insects on Nubariya and Damanhour regions.

\section{MATERIALS AND METHODS}

This investigation was conducted at the experimental farm Nubariya Agricultural Research Station, West Nubariya and Damanhour (Hafs village), Al Behera governorate during two successive seasons, 2010/2011 and 2011/2012, to study the susceptible seven sugarbeet cultivars to infestation with tortoise beetle Cassida vittata Vill, and their yield and quality characteristics. The three pesticides (Radiant SC ${ }^{\complement} 12 \%$, Dursban $^{\odot} \mathrm{H}$ 48\% EC and Mospilan ${ }^{\odot} 20 \%$ SP) were tested against $C$. vittata. Also, study of the interaction between cultivars and insecticides and their impact on the quantity and quality of sugarbeet plants

\section{Sugar beet material.}

Seven sugarbeet cultivars used in this study introduced from Sugar Croup Research Institute, Agriculture Research Center, Egypt. The seven sugarbeet cultivars were four monograms Helsinki, Ravel, MK2134 and Sible and three polyograms cultivars Oscar poly, Gazella and Lilly).

\section{The tested pesticides}

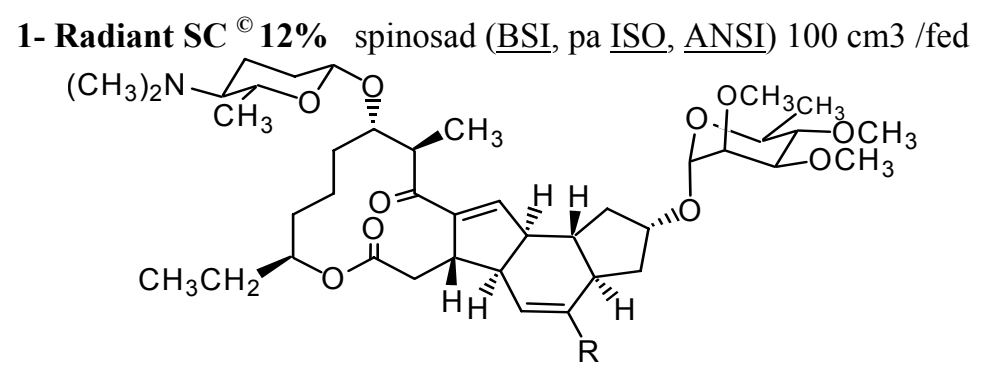

spinosyn $A, R=H-$

spinosyn $\mathrm{D}, \mathrm{R}=\mathrm{CH}_{3}$

2- Mospilan ${ }^{\odot}$ SP 20\%acetamiprid (pa $\underline{\text { ISO) }} \mathrm{C}_{10} \mathrm{H}_{11} \mathrm{ClN}_{4} 25 \mathrm{~g} / 100$ liter<smiles>CN=C(C)N(C)C</smiles>

3- Dursban ${ }^{\odot}$ EC 48\% O, O-diethyl O-(3, 5,6-trichloro-2-pyridinyl) phosphorothioate 


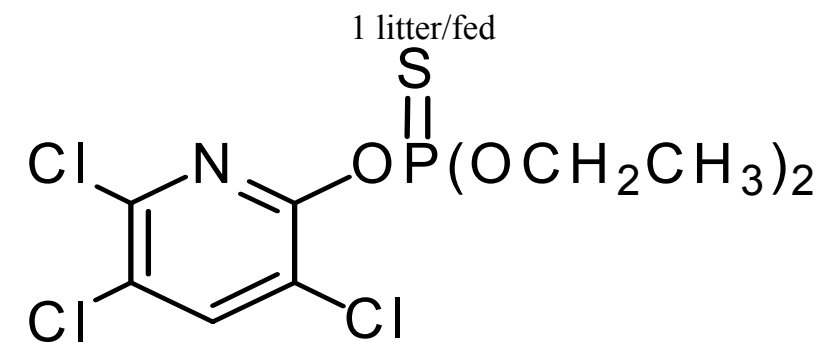

The split plot design with three replicates was, used. Seven cultivars, (four monograms Helsinki, Ravel, MK2134 and Sible and three polyograms cultivars Oscar poly, Gazella and Lilly) were randomly distributed in the main plot and the three insecticides were randomly allotted in the sub plot. Each sub plot included 14 ridges, $50 \mathrm{~cm}$ apart and $10 \mathrm{~m}$ length thus the plot area was $70 \mathrm{~m}^{2}$. However, the mineral fertilizer, ammonium nitrate $(33.5 \%)$ added at 80 unit of nitrogen per feddan in three equal portions at 30,60 , and 90 days after sowing. Seven sugarbeet cultivars sown on the November $1^{\text {st }}$ in both seasons at the two locations (Nubariya and Damanhour regions). Seeds sown in hills, $20 \mathrm{~cm}$ apart .Thirty days after sowing; thinning to one plant per hill was carried out before fertilization. Mechanical and chemical analysis of the soil by Ministry of Agriculture Authority Public for Agricultural Fund Budget, soil fertility Damanhour lab for used in the present study are shown in Table (1).

The first sample of insect pests was taken after eight weeks from sowing. Monthly samples ( 5 plants / plots), were randomly collected along the period of growing season. Each sample put in plastic bag at different dimensions according to the status of plant growth to transport to the laboratory. The sample plants were carefully examining for counting the larva and adults of tortoise beetle $C$. vittata according to Abo El-Ftooh (2002). Pesticides were applied in both Nubariya and Damanhur regions in the first and second seasons $\left(15^{\text {th }}\right.$ March) on the more sensitive Siebel cultivar (based on the results of the first season) in the second season. Population reductions due to treatments were calculated and compared with the insect numbers in untreated plots (control). Percentage of infestation reduction of such cases was estimated according to the formula of Henderson and Telton (1955).

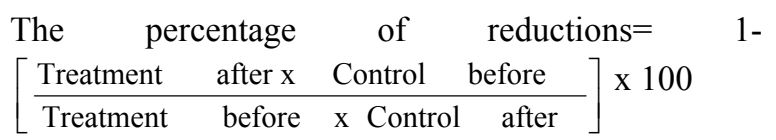

Where,

Treatment after $=$ The number of collected alive insects from the plot after treatment
Treatment before $=$ The number of collected alive insects from the plot before treatment

Control after $=$ the number of collected alive insects from the check plot after the date of treatment

Control before $=$ the number of collected alive insects from the check plot before the date of treatment. The relative population densities of $C$. vittata (larvae and adults) were recorded for seven times, i.e., 1, 3, 5, 7,14 and 21 days.

At harvest (210 days from sowing), Sample each plot was used to estimate roots, top and sugar yields (ton/fed). In addition, the quality characteristic in sugarbeet roots included sucrose percentage, total soluble solids (T.S.S) and juice purity percentages were recorded in laboratory of Nile Sugar Company, Egypt.The insecticides were applied at Nubariya and Damanhour regions at $15^{\text {th }}$ March, through two seasons.

\section{RESULTS AND DISCUSSIONS}

\section{1- Population density of, Cassida vittata Vill}

Data in table (2) identified the population fluctuation of C.vittata (larvae and adults) which attacked seven cultivars at two regions through 2010/11 and 2011/12 seasons. In January, the Sible cultivar was recorded as the highest number of tortoise beetle C.vittata in to seasons $(9,7,15$ and 8 larvae and adults/ 5plants) at two regions and two seasons. While the Helsinki cultivar recorded in the same period $(2,0,9$ and 8 larvae and adults/ plants) at two regions, respectively. In the mid season (March) the Helsinki variety surpassed in resistant to tortoise beetle and recorded the lowest numbers of C.vittata (32, 38, 39 and 49 larvae and adults 5/plants) respectively. These results were harmony with Salama and Elnagar (1993). They reported that an apparent outbreak of the tortoise beetle Cassida vittata was observed in 1988/89 season. On the other side, the Sible cultivar was recorded the highest numbers of larvae and adults of C.vittata in the same period on investigation $(36,34,44$ 
Table 1. Chemical and physical properties of the experimental Soil in Damanhour and Nubariya regions during 2010/2011 and $2010 / 2011$ seasons

\begin{tabular}{|c|c|c|c|c|c|c|c|c|c|}
\hline \multicolumn{4}{|c|}{$\begin{array}{c}\text { Nutrients } \\
\text { P.P.M } \\
\end{array}$} & \multirow[b]{2}{*}{ 竭 } & \multirow{2}{*}{$\begin{array}{c}\text { Sodium dissolved } \\
\text { in water }(1: 5)\end{array}$} & \multicolumn{2}{|c|}{$\begin{array}{c}\text { Total dissolved salts } \\
(1: 5) \\
\end{array}$} & \multirow[b]{2}{*}{$\underset{\stackrel{a}{a}}{\stackrel{a}{a}}$} & \multirow[b]{2}{*}{ 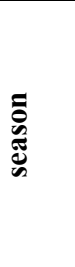 } \\
\hline อี & 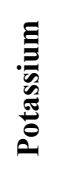 & 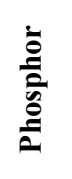 & 总 & & & $\begin{array}{l}\stackrel{\mathscr{E}}{\tilde{E}} \\
\frac{0}{0} \\
0^{\circ}\end{array}$ & ○ิ & & \\
\hline \multicolumn{10}{|c|}{ Damanhour region (Soil type: clay) } \\
\hline 0.3 & 23 & 4 & 70 & 2.9 & 5.21 & 0.32 & 1.02 & 8.4 & $1^{s t}$ \\
\hline 0.48 & 34 & 6 & 80 & 4.2 & 7.5 & 0.4 & 1.24 & 8.3 & $2^{\text {nd }}$ \\
\hline \multicolumn{10}{|c|}{ Nubariya region (Soil type: sandy loam) } \\
\hline 0.4 & 45 & 10 & 70 & 5.4 & 2.3 & 0.17 & 0.52 & 8.3 & $1^{s t}$ \\
\hline 0.48 & 58 & 8 & 40 & 2.5 & 6.3 & 0.31 & 0.98 & 8.5 & $2^{n d}$ \\
\hline
\end{tabular}

Soil depth (cm): $0-40 \mathrm{~cm}$

and 55 larvae and adults /plants). On the day of harvest showed both cultivars Helsinki and Sible cultivars gave the same direction which Helsinki cultivar was more resistant(44, 51,47 and 53 larvae and adults /plants) while Sible cultivar was more susceptible to infection by tortoise beetle C.vittata,(53, 54,49 and 56 larvae and adults /plants) in two region and two seasons , respectively. Results took the a straight line form rising during the experience period during seasons and locations under the study

Data in Table (2) explained that the population fluctuation of C.vittata (numbers of larvae and adults) were increasing whenever plants became larger in a lifetime.

In the end of both seasons and in the two regions, the combined analysis demonstrated that the Helsinki cultivar was more resistant to larvae and adults of C.vittata. Conversely, Sible cultivar was more sensitive to tortoise beetle C.vittata (51 and larvae and adults /plants).Cultivars can be arranged ascending order at harvest crop, according to attract cultivars of tortoise beetle as follow: Helsinki, Mk 2134 , Gazella, Ravel, Lilly, Oscar poly, and Sibel (48.8, 49.8, 50.3, 50.8, 51.3 , 52.4 and 55.9), respectively. These results are in agreement with those obtained by Zarif, and Hegazi (1990) and Abo El Ftooh(1995). They reported that, there are differences the degree of resistance on cultivars tested to beet fly Pegomyia mixta Vill (Diptera Anthomyidae) and Cassida vittata Vill.

2: Yield and quality parameters for seven sugarbeet cultivars at Nubariya region and Damanhour region.

\subsection{Root yield parameter}

Data recorded in Table (3) identified the yield and quality for seven cultivars of sugar beet crop during two seasons in each of Nubariya and Damanhur regions.In the first and second seasons Helsinki cultivar was distinguished on the other cultivars for root yields parameter which recorded the (22. 3 and 22.8 ton/fed). On the other hand, Sibel cultivar was the lowest productivity of root yield (18.8 ton/fed) in the first season, while Mk 2134 cultivar had less produced root yield (19.4 ton/fed) in the second season. There were significant differences between seven cultivars in the first and the second seasons. Combined analysis of root yield parameter illustrated in Table (3) that Helsinki cultivar was recorded the highest value of root yield (22.6 ton/fed) while, the Mk 2134 and Lilly were equaled on productive the less root yield (19.8 tons /fed). There were significant differences between all cultivars under study. These results are in harmony with those obtained by Korayem (2006) which he found that sugarbeet cultivars were influencing in severity of rootknot nematode resistance and these characteristics were affected to varying degrees seven cultivars can be arranging by the productivity of crop roots descending order as follows: Helsinki, Oscar poly, Gazella, Sibel, Ravel, Mk 2134 and Lilly.

\subsection{Leaves yield parameter:}

Data in Table (3) observed that, Helsinki cultivar recorded the highest values of top yield $(8.9,10.0$ ton/fed) during (2010/11 and 2011/12) seasons. On the other hand, Lilly cultivar recorded the lowest top yield (7.1 ton/fed) in the first season but Gazella and Sibel cultivars were produced the lowest value $(8.6$ ton/fed) of 


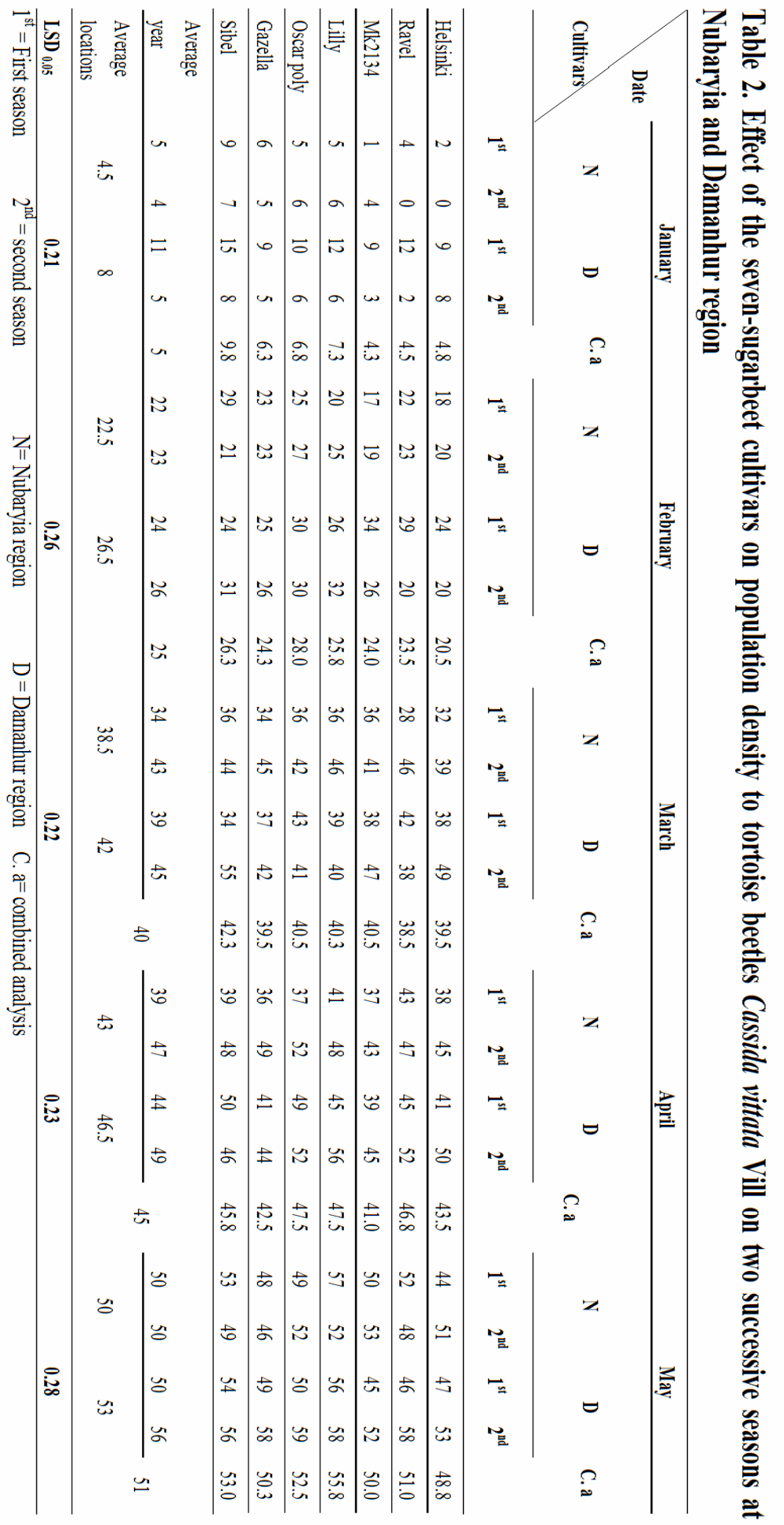


Table 3. Combined analysis to seven sugarbeet cultivars as yield and quality characters at Nubaryia and Damanhur region, in two successive seasons

\begin{tabular}{|c|c|c|c|c|c|c|c|c|c|}
\hline \multirow{2}{*}{$\begin{array}{l}\text { Sugarbeet } \\
\text { Cultivars }\end{array}$} & \multicolumn{3}{|c|}{$\begin{array}{c}\text { Root yield } \\
\text { (ton/fed) }\end{array}$} & \multicolumn{3}{|c|}{$\begin{array}{l}\text { Top yield } \\
\text { (ton/fed) }\end{array}$} & \multicolumn{3}{|c|}{$\begin{array}{c}\text { Sugar yield } \\
\text { (ton/fed) }\end{array}$} \\
\hline & $1^{\text {st }}$ & $2^{\text {nd }}$ & C. $\mathbf{a}$ & $1^{\text {st }}$ & $2^{\text {nd }}$ & C. $\mathbf{a}$ & $1^{\text {st }}$ & $2^{\text {nd }}$ & C. $\mathbf{a}$ \\
\hline Helsinki & 22.3 & 22.8 & 22.6 & 8.9 & 10.0 & 9.4 & 3.5 & 3.6 & 3.5 \\
\hline Ravel & 20.5 & 21.5 & 20.1 & 7.4 & 8.7 & 8.1 & 3.1 & 3.4 & 3.3 \\
\hline Mk2134 & 20.2 & 19.4 & 19.8 & 7.6 & 9.1 & 8.3 & 2.7 & 3.1 & 2.9 \\
\hline Lilly & 19.5 & 20.1 & 19.8 & 7.1 & 9.2 & 8.1 & 3.1 & 3.2 & 3.15 \\
\hline Oscar poly & 20.8 & 19.6 & 21.2 & 7.5 & 8.9 & 8.2 & 3.2 & 3.4 & 3.3 \\
\hline Gazella & 21.0 & 21.1 & 21.1 & 7.7 & 8.6 & 8.2 & 3.1 & 3.3 & 3.2 \\
\hline Sibel & 18.8 & 21.6 & 20.2 & 7.9 & 8.6 & 8.3 & 3.4 & 3.4 & 3.4 \\
\hline Average & 20.6 & 20.7 & 20.5 & 7.7 & 9.0 & 8.3 & 2.5 & 2.9 & 2.7 \\
\hline LSD $_{0.05}$ cultivars & \multicolumn{2}{|c|}{0.14} & 029 & \multicolumn{2}{|c|}{0.08} & 0.75 & \multicolumn{2}{|c|}{0.03} & 0.06 \\
\hline
\end{tabular}

top yield parameter. In addition, combined analysis revealed that Helsinki cultivar was higher produced of leave yield (9.4 ton/fed) while the lowest top yield values was produces by Ravel and Lilly cultivar (8.1 ton/fed).

\subsection{Sugar yield parameters:}

Consequently, data signaled in Table (3) showed that, Helsinki cultivar was continuing in outweigh of sugar yield parameter under this part of study. In 2010/11and 2011/12 seasons the Helsinki cultivar recorded the highest values (3.5 and 3.6 tons/yield) respectively. From, the combined analysis data cleared that Helsinki cultivar was more produced sugar yield (3.5 ton/fed) than other cultivars under investigation. Whereas, Mk 2134 cultivar exhibited the lowest values (2.7 and 3.1 tons /fed) during the two seasons. Nevertheless in the combined analysis data reported that Mk 2134 cultivar was less productivity (2.9 ton/fed) than sugarbeet cultivars. There were significant differences between the cultivars under examination for this character through the two seasons, as well as data for combined analysis gave significant differences between cultivars.

\subsection{Tatal Soluble Solid (T.S.S \%):}

Data in Table (4) noticed that sugarbeet cultivars Oscar poly (20.1\%) recorded the highest value of Total Soluble Solid (T.S.S \%) in the second season. While, cultivars Helsinki and Mk2134 equaled in T.S.S percentage $(20.4 \%)$ values through in the second season. However, Lilly cultivar was recorded the lowest value of T.S.S. \% parameter $(19.0 \%)$ in the first season, but Gazella cultivar was recorded the least value of T.S.S.\% (18.9\%) during the second season2011/2012. The combined analysis illustrated that, Helsinki cultivar was recorded the highest value of T.S.S. \% (20.1\%). In contrast, the Ravel and Gazella cultivars recorded the lowest values of T.S.S. \% values (19.2\%) in the second seasons. From previous data, it can be observed that there were no significant differences among the cultivars cultivated except Ravel and Gazella cultivars and Mk 2134 and Oscar poly. Addition, cultivars can be arranged in ascending order according to the values of T.S.S \% as follow: Gazella, Ravel, Lilly, Sibel, Mk 2134, Oscar poly and Helsinki cultivars.

\subsection{Sucrose percentage:}

Data in Table (4) Indicated that Helsinki cultivar gave the highest values of sucrose percentage (16.1\%) in combined analysis for two years while the Lilly cultivars recorded less values of sucrose percentage $(15 \%)$ for the same period. On the other side, Oscar poly cultivar recorded the highest sucrose percentage $(16.1 \%)$ on the first season. While, in the second season the Gazelle cultivar was recorded the lowest value of sucrose $(15 \%)$.

\subsection{Purity percentage:}

Data in Table (4) indicated that Helsinki and Oscar poly cultivars recorded the highest values of purity $\%$ in the first season $(79.9 \%)$. In addition, Helsinki cultivar recorded the highest values of purity percentage in the second season and there was no significant difference between Helsinki and Oscar Poly cultivars (80.1 and $80 \%$ ) respectively. The combined variation analysis observed that Helsinki cultivar (80\%) exceed the other cultivars in this study at two regions and in two seasons as well. In the other the trend, Mk2134 was recorded the lowest values of purity percentage (78.1 and 78.8 $\%$ ) in two growing seasons, respectavily. As well as, combined analysis data reported that Mk2134 cultivar was less purity percentage value $(78.5 \%)$ than anther cultivars 
Table 4. Combined analysis to seven sugarbeet cultivars as quality characters at Nubaryia and Damanhur region, in two successive seasons

\begin{tabular}{lccccccccc}
\hline \multirow{2}{*}{$\begin{array}{l}\text { Sugarbeet } \\
\text { Cultivars }\end{array}$} & \multicolumn{3}{c}{ T.S.S \% } & \multicolumn{4}{c}{ Sucrose \% } & \multicolumn{3}{c}{ Purity \% } \\
\cline { 2 - 11 } & $\mathbf{1}^{\text {st }}$ & $\mathbf{2}^{\text {nd }}$ & $\mathbf{C . ~ a}$ & $\mathbf{1}^{\text {st }}$ & $\mathbf{2}^{\text {nd }}$ & $\mathbf{C . ~ a}$ & $\mathbf{1}^{\text {st }}$ & $\mathbf{2}^{\text {nd }}$ & C. $\mathbf{a}$ \\
\hline Helsinki & 19.8 & 20.4 & 20.1 & 15.8 & 16.3 & 16.1 & 79.9 & 80.1 & 80.0 \\
\hline Ravel & 19.6 & 18.8 & 19.2 & 15.6 & 14.8 & 15.2 & 79.4 & 78.9 & 79.1 \\
\hline Mk2134 & 19.6 & 20.4 & 19.9 & 15.3 & 16.1 & 15.6 & 78.1 & 78.8 & 78.5 \\
\hline Lilly & 19.0 & 20.2 & 19.6 & 15.0 & 16.2 & 15.6 & 78.9 & 80.2 & 79.6 \\
\hline Oscar poly & 20.1 & 19.7 & 19.9 & 16.1 & 15.8 & 15.9 & 79.9 & 80.0 & 79.9 \\
\hline Gazella & 19.5 & 18.9 & 19.2 & 15.4 & 15.0 & 15.2 & 79.1 & 79.3 & 79.2 \\
\hline Sibel & 19.9 & 19.7 & 19.8 & 15.8 & 15.7 & 15.7 & 79.2 & 79.5 & 79.4 \\
\hline Average & 19.6 & 19.7 & 19.7 & 15.5 & 15.7 & 15.7 & 79.2 & 79.5 & 79.5 \\
\hline $\begin{array}{l}\text { LSD } 0.05 \\
\text { cultivars }\end{array}$ & \multirow{2}{*}{0.12} & & 0.27 & \multicolumn{2}{c}{0.12} & 0.30 & 0.19 & 0.35 \\
\hline
\end{tabular}

3. The reduction population of tortoise beetle Cassida vittata Vill on sugarbeet crop by used three pesticides.

Three Pesticides were tested against tortoise beetle C.vittata (larvae and adults) which infested plots cultivated by Sibel cultivar showed more susceptible to infection beetle in the two seasons at two regions Nubariya and Damanhur. From, Table (5 and6) in the fist day at Nubariya region Radiant SC ${ }^{\circ} 12 \%$ reduction percentage was (12and 9.5) for larvae and adults with mean reduction percentage $(10.75 \%$ larvae \&adults) .While the same pesticide Radiant $\mathrm{SC}^{\circledR}$ at Damanhur region the reduction percentage in the first day was (17 and $13 \%$ ) for larvae and adults with mean reduction $\%(15 \%)$. In $7^{\text {th }}$ day the Radiant SC ${ }^{\circ} 12 \%$ recorded (56 and 40) for larvae and adults with mean reduction percentage (48\%) and (58 and 50) for larvae and adults with mean (54\%) at Nubariya and Damanhur regions, respectively. In the end period the reduction percentage resulting to applied by day Radiant SC ${ }^{\circ} 12 \%$ (87 and $85 \%$ ) for larvae and adults with mean $(86 \%)$ at Nubariya regions. In the corresponding period at Damanhur region the reduction percentages were $(92$ and $87 \%$ ) for larvae and adults with mean $(89.5 \%)$. These results were corresponded with Nehad et al (2008) which stated that Radiant SC ${ }^{\circledR}$ $12 \%$ was more toxic on Spodoptera littoralis. The second efficacy of pesticides was Mospilan ${ }^{\odot} 20 \%$ SP pesticide, in $1^{\text {st }}$ day was recorded (10 and 4) for larvae and adults with mean reduction $\%(7 \%)$ at Nubariya region while at Damanhur region in the first day recorded (9and 5\%) for larvae and adults with mean reduction $\%(7 \%)$. In the $7^{\text {th }}$ day Nubariya region Mospilan $^{\circ}$ SP $20 \%$ was more toxic in larvae stage $(30 \%)$ of C.vittata than adults $(20 \%)$ with mean reduction (31\%).Also in at Damanhur region, the reduction percentage was $(25 \%)$ for larvae instars and
$(20 \%)$ adults stage with mean reduction $(23 \%)$. This result were compatible with these obtained by Ali et al (2012) who found that acetamiprid (Mospilan ${ }^{\odot}$ SP) is a new generation from neonicotinoid insecticides and highly active to protect the various vegetable crops, by controlling mites and insect pests. At the end period application the Mospilan ${ }^{\circ} 20 \%$ SP was more killing for larvae than adults (80 and $73 \%$ e) for larvae and for adults (76 and 60\%) at Nubariya and Damanhur regions, respectively. As well as, the mean reduction was recorded higher reduction percentage in Damanhur region $(67 \%)$ than Nubariya region $(78 \%)$. The third pesticides Dursban ${ }^{\circ}$ EC $48 \%$ was less reduction percentage against tortoise beetle $C$. vittata (larvae and adults) at Nubariya region during applying period. But the Dursban ${ }^{\circ}$ EC $48 \%$ was superiority during some periods of experiment. These results are in accordance with EL-Kholy and Omar (2002) and Asmahan and Qasem (2004).They reported that the efficiency of chlorfenapyr was evaluated against eggs, larvae, pupae and adults of the tortoise beetle Cassida vittata chlorfenapyr demonstrates highly toxic effect.

\section{The interaction between seven cultivars and three pesticides}

\subsection{Root yield parameter.}

Data resulted in Table (7) determined that Helsinki cultivar with Radiant SC ${ }^{\circledR} 12 \%$ found to be the most productive (25.06 ton/fed) in root yield than interaction between the same cultivar and two other pesticides (22.28 and 21.32 ton/fed). Also, the interaction between Radiant SC ${ }^{\circ}$ pesticide and the rest of cultivars was recorded the highest productivity in root yield except pesticide interaction with two cultivars Oscar Poly (23.28 tons/ fed) and Gazella (21.90 tons /fed), respectively. While, Mospilan ${ }^{\mathbb{C}} 20 \%$ SP pesticide 

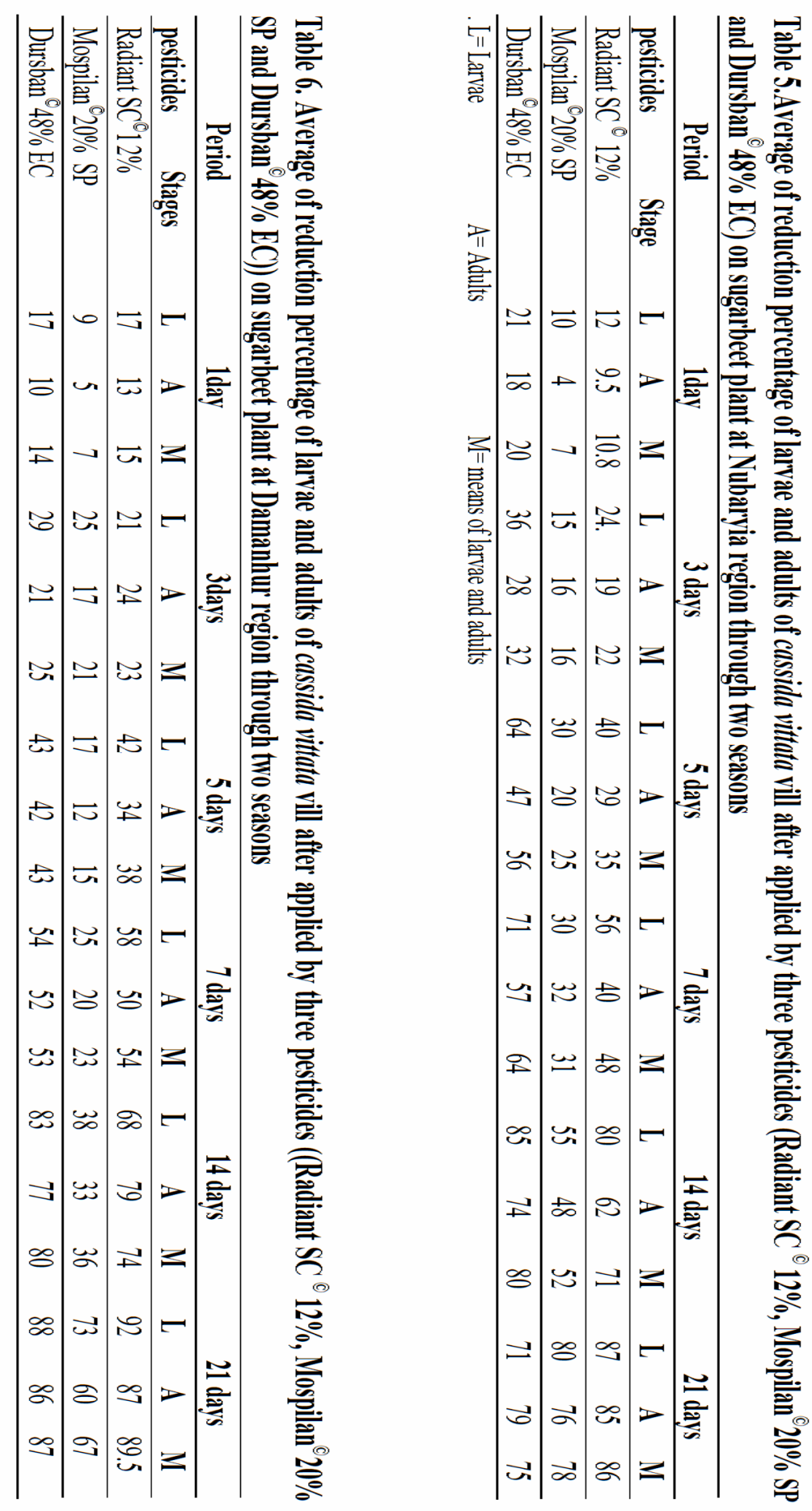
Table 7. Effect of interaction between seven cultivars and three pesticides, on sugarbeet yield and quality characters

\begin{tabular}{|c|c|c|c|c|c|c|c|}
\hline Cultivars & Treatments & $\begin{array}{l}\text { Root Yield } \\
\text { (ton/fed) }\end{array}$ & $\begin{array}{l}\text { Top yield } \\
\text { (ton/fed) }\end{array}$ & $\begin{array}{c}\text { Sugar yield } \\
\text { (ton/fed) }\end{array}$ & $\begin{array}{c}\text { T.S.S } \\
\%\end{array}$ & $\begin{array}{c}\text { Sucrose } \\
\%\end{array}$ & Purity\% \\
\hline \multirow{4}{*}{ Helsinki } & Radiant $\mathrm{SC}^{\circledR} 12 \%$ & 25.06 & 9.53 & 4.00 & 20.93 & 17.0 & 81.00 \\
\hline & $\operatorname{Mospilan}^{(} 20 \% \mathrm{SP}$ & 21.32 & 8.53 & 3.85 & 20.71 & 16.5 & 79.54 \\
\hline & Dursban $^{\odot}$ EC48\% & 22.28 & 9.36 & 3.64 & 20.67 & 16.5 & 79.75 \\
\hline & Control & 17.61 & 7.73 & 2.66 & 17.93 & 14.0 & 78.04 \\
\hline \multirow{4}{*}{ Ravel } & Radiant SC ${ }^{\odot} 12 \%$ & 24.60 & 9.31 & 3.00 & 19.52 & 15.5 & 79.50 \\
\hline & Mospilan $^{\circ} 20 \% \mathrm{SP}$ & 18.85 & 8.27 & 3.15 & 20.20 & 16.1 & 79.50 \\
\hline & Dursban $^{\circ}$ EC48\% & 23.21 & 8.60 & 3.18 & 19.32 & 15.3 & 79.08 \\
\hline & Control & 17.28 & 7.61 & 2.18 & 17.79 & 14.0 & 78.63 \\
\hline \multirow{4}{*}{ Mk2134 } & Radiant SC ${ }^{\odot} 12 \%$ & 24.04 & 8.88 & 3.54 & 19.92 & 15.7 & 79.04 \\
\hline & Dursban $^{\circ}$ EC48\% & 21.27 & 8.57 & 3.78 & 20.83 & 16.5 & 79.29 \\
\hline & Mospilan $20 \%$ SP & 18.23 & 8.99 & 3.68 & 21.00 & 16.6 & 78.88 \\
\hline & Control & 16.05 & 6.91 & 2.20 & 18.04 & 13.8 & 76.63 \\
\hline \multirow{4}{*}{ Lilly } & Radiant SC ${ }^{\odot} 12 \%$ & 22.53 & 8.48 & 3.23 & 19.92 & 15.9 & 79.71 \\
\hline & Mospilan $20 \%$ SP & 19.12 & 8.02 & 2.91 & 20.03 & 16.1 & 80.25 \\
\hline & Dursban $^{\odot}$ EC48\% & 20.94 & 8.47 & 3.19 & 19.72 & 15.9 & 80.58 \\
\hline & Control & 16.67 & 7.59 & 2.19 & 18.48 & 14.4 & 77.67 \\
\hline \multirow{4}{*}{$\begin{array}{l}\text { Oscar } \\
\text { poly }\end{array}$} & Radiant SC ${ }^{\odot} 12 \%$ & 23.28 & 8.60 & 3.61 & 20.46 & 16.3 & 79.63 \\
\hline & Mospilan $^{\circ} 20 \%$ SP & 20.13 & 8.24 & 3.59 & 20.29 & 16.5 & 81.11 \\
\hline & Dursban $^{\circ}$ EC48\% & 23.50 & 8.56 & 3.68 & 20.26 & 16.3 & 80.46 \\
\hline & Control & 18.03 & 7.28 & 2.23 & 18.43 & 14.2 & 77.08 \\
\hline \multirow{4}{*}{ Gazella } & Radiant SC ${ }^{\odot} 12 \%$ & 21.90 & 8.10 & 3.31 & 20.00 & 16.0 & 80.20 \\
\hline & Mospilan $^{\circledR} 20 \% \mathrm{SP}$ & 21.00 & 8.30 & 3.45 & 21.33 & 17.2 & 80.50 \\
\hline & Dursban $^{\odot}$ EC48\% & 22.30 & 7.90 & 3.32 & 19.30 & 15.3 & 79.53 \\
\hline & Control & 18.03 & 6.58 & 2.33 & 18.55 & 14.5 & 78.08 \\
\hline \multirow{4}{*}{ Sibel } & Radiant SC ${ }^{\odot} 12 \%$ & 22.31 & 8.23 & 3.55 & 20.59 & 16.7 & 81.04 \\
\hline & Mospilan $20 \%$ SP & 19.43 & 8.18 & 3.80 & 19.98 & 15.9 & 79.58 \\
\hline & Dursban $^{\odot}$ EC48\% & 21.67 & 8.30 & 3.85 & 21.04 & 16.9 & 80.13 \\
\hline & Control & 17.39 & 7.33 & 2.53 & 17.67 & 13.6 & 76.79 \\
\hline \multicolumn{2}{|c|}{$\begin{array}{l}\text { LSD } 0.05 \text { btween cultivars and } \\
\text { treatments }\end{array}$} & 0.29 & 0.75 & 0.06 & 0.27 & 0.25 & 0.35 \\
\hline
\end{tabular}

recorded the lowest interaction values with seven cultivars. The lowest value of interaction recorded by Mk2134 cultivar (18.25tos/fed). Dursban ${ }^{\circledR}$ EC 48\% pesticide was the second productive of sugarbeet root yield as a result of its interaction with the seven cultivars tested. Interaction between Dursban ${ }^{\circ}$ EC $48 \%$ and Oscar poly cultivar produced the highest root yield (23.50 tons /fed), also, the interaction between Ravel cultivar and Dursban ${ }^{\circ}$ EC $48 \%$ gave the second order in root yield (23.21 tons /fed) and there were no significant differences among the two interaction. On the other hand, the lowest value was obtained by the interaction between Dursban ${ }^{\odot}$ EC 48 pesticide and Lilly cultivar (20.94 ton/fed).

\subsection{Top yield parameters:}

Data in Table (7) reported that Helsinki and Ravel cultivars which interacted with Radiant SC ${ }^{\circ} 12 \%$ gave the highest top yield (9.53 and 9.31 ton/fed) respectively. Possible arrangement pesticide Radiant SC ( ) $12 \%$ interaction of with items descending in accordance with the values of top yield as follow: Helsinki cultivar (9.53 ton/fed), Ravel (9.31ton/fed), Mk2134 (8.88 ton/fed), Oscar poly (8.60 ton/fed), Lilly (8.48 ton/fed), Sibel (8.23 ton/fed) and Gazella (8.10 ton/fed). With regard to interaction between insecticides and cultivars the lowest value was obtained (7.90 tons/ fed). On the other hand, Mospilan ${ }^{\odot}$ SP $20 \%$ recorded the highest value of interaction between this pesticide and Mk2134 cultivar (8.99 ton/fed). While the lowest value of interaction between the same insecticides and Lilly cultivar (8.02 tons /fed). There were significantly affected between interaction for all pesticides and cultivars to this parameter under study. 


\subsection{Sugar yield parameter:}

Data in Table (7) revealed that, interaction between Helsinki cultivar and their pesticides confirmed that reaction of Radiant SC ${ }^{\odot} 12 \%$ pesticide and Helsinki cultivar produced highest sugar yield value (4.00 ton/fed). While, less value of interaction between Helsinki cultivar and two other pesticides recorded by Dursban $^{(}$EC $48 \%$ pesticide (3.65 ton/fed) where preceded by the pesticide Mospilan ${ }^{\odot}$ SP 20\% (3.85 ton/fed). In contrast, data in Table (7) cleared that, interaction between other cultivars under investigation and the three pesticides recorded the lowest values of sugar yield produced by Mospilan ${ }^{\odot}$ SP $20 \%$ Lilly cultivar (2.91 tons /fed). In addition, there were significant differences for values of sugar yield character which effected by interaction between the cultivated seven cultivars and pesticides, which applied on field.

\section{4 .Total Soluble Solid percentage T. S.S. \%:}

Data recorded in Table (7) stated that T.S.S. \% influenced by interaction between the pesticide and cultivars. The highest value of T.S.S. resulted in interaction between Gazella cultivar and Mospilan ${ }^{\odot} \mathrm{SP}$ $20 \%(21.33 \%)$. The similar cultivar recorded the lowest value with at the spraying Dursban ${ }^{\odot}$ EC $48 \%$ (19.30\%). From the General point of consideration of T.S.S\% value obtained from the interaction of cultivars and pesticides found other cultivars (Sibel) with Dursban ${ }^{\circledR}$ EC $48 \%$ pesticide $(21.04 \%)$.As well as, the Gazella cultivar and Dursban ${ }^{\circ}$ EC 48\% recorded (19.30\%). From previous data for Total Soluble Solids percentage values resulted interaction with Mospilan ${ }^{\odot}$ SP pesticide gave the highest values by interaction with all cultivars except Siebel product (19.98\%). There were significant differences for values of the interaction between seven cultivars and pesticides.

\subsection{Sucrose percentage}

From the combined analysis data recorded in Table (7) showed that the interaction between pesticides and cultivars were recorded the highest value of the sucrose percentage after the application of a pesticide Mospilan $^{\odot}$ SP $20 \%$ with Gazelle $(17.2 \%)$. On other hand, pesticide Dursban ${ }^{\circ}$ EC $48 \%$ was recorded the lowest value of sucrose \% after applied with Ravel and Gazelle cultivars (15.3\%).

\subsection{Purity percentage}

Data obtained from Table (7) between pesticides and cultivars recorded that the highest values of purity percentage resulted by applied Mospilan ${ }^{\odot}$ SP 20\% pesticide with Oscar poly cultivar $(81.11 \%)$ and then Radiant SC ${ }^{\odot} 12 \%$ with Sibel cultivar $(81.04 \%)$ and finally Radiant SC ${ }^{\circ} 12 \%$ with Helsinki cultivar (81.00).
However, the data showed the lowest value of purity percentage by spraying Mospilan ${ }^{\odot}$ SP $20 \%$ on MK2134 cultivar $(78.88 \%)$ than all treatments. There were significant differences between the interaction which the application of pesticides with tested cultivar to study this variable.

\section{CONCLUSION}

Helsinki Cultivar was surpassed resistance to tortoise beetle, Cassida vittata. In addition, the same cultivar was superiority in most yield attributes such as root, top, and sugar yields and sucrose and purity percentage. As well as Radiant SC ${ }^{\circ} 12 \%$ exceed all cultivars when spraying and interaction with seven cultivars in all the attributes except T.S.S. Radiant SC ( $12 \%$ pesticide was more toxic against tortoise beetle Cassida vittata Vill (Larvae and Adults) in two regions through two seasons.

\section{REFERENCES}

Abo El-Ftooh, A. A. (1995). Studies on the sugar beet insect Cassida vittata Vill. (Coleoptera Chrysomelidae). M. Sc. Thesis, Plant Protection Dept., Faculty of Agriculture, Saba Basha, Alexandria Univ., Egypt. 170.

Abo El-Ftooh, A. A. (2002). Biological control of the tortoise beetle, Cassida vittata on sugar beet. Ph.D. Thesis, Fac. of Agric., Moshtohor, Zagazig. Uni., (BbanhaBranch).262pp

Abo El Ftooh, A. A.; O. M. Badawy and M.M Abd El Rahman(2007). Screening of nineteen new sugar beet (Beta vulgaris L .) varieties for the tortoise beetle, (Cassida vittata Vill.) resistance and yield at Nubaryia region, Egypt. J. Agric .sci. Mansoura Unive., 32(1) :653660.pp .

Ali M. SEl Din, 1M.M. Azab, 1Tahany R. Abd El-Zaher, 2Z.H.A. Zidan and 1Amany R. Morsy (2012) .Persistence of Acetamiprid and Dinotefuran in Cucumber and Tomato Fruits. American-Eurasian Journal of Toxicological Sciences 4 (2): 103-107.

Annual Report of Sugar Crops Council (2012). Sugar Crops Council, Ministry of Agriculture and Land Reclamation, Giza, Egypt.

Asmahan, A.Y. and Qasim, S. A.A. (2004) Efficacy of certain bio and chemical insecticides against sugar beet fly and sugar beet tortoise beetle and associated predators on sugar beet plants in kaer El-Sheikh region Journal of Agricultural Sci. Mansoura Uni. 29(5): 2833-2838.

Bassuony, A. M.; A. M. Ebieda and Arifa G. Solouma (1993) Studies on sugarbeet pests. II. Periodical effect of plant growth regulators on the population density of the common sugarbeet insects. Alex. Sci. Exch. 14: 115-28 
Chawdhery,R. A. (2012). The effects of nitrogen fertilizer rates in a long-term reduced tillage cropping system on dry matter and nitrogen accumulation in an oil radish (Raphanus sativus L.) cover crop. M. Sc. Thesis, A2E Agroecology- Master's Programmer Department of Agrosystems, SLU Alnarp 2012.

Cook, D.A and Scot, R.A. t(1993). The sugarbeet crops.11pest Published by Chapman and Hall ISBN 0412251302P.429-483.

El-Khouly, M. I. (1998). Ecological studies and control of the tortoise beetle, Cassida vittata de Villers in sugar beet ecosystem. Ph. D. Thesis, Fac. Agric., Al-Azhar Univ., $183 \mathrm{pp}$.

EL-Kholy M. I. and. Omar B.A.(2002). The efficiency of some insecticides on tortoise beetle Cassida vittata Vill inhabiting sugarbbet field. Egyptian Journal of Agricultural Research, V. 80, 2: 1889-1901

Ferry,N.; Edwards MG; Gatehouse, J.; Capell, T.; Christou, P.; Gatehouse A. M. (2006). Transgenic plants for insect pest control: a forward looking scientific perspective. Transgenic Reserch, 15: 13- 19.

Hammad SM. 1955. On some dipterous leaf-miners. Egypt Bull Soc Entomol Egypt. 33:391-393.

Hatem Fouad, Ali Abd El-Hady and El-Sayed Sherief(2012) Controlling some pests

infesting sugar-beet in sharkia governorate: insects controlling on sugar beet. J. Biological Sci., 2 (1); 8-13.

Korayem, A.M. (2006). Relationship between Meloidogyne incognita Density and Damage to Sugar Beet inSandy Clay Soil. Egypt. J. Phytopathol., Vol. 34, No.1, pp. 6168

Mesbah I, Fayez A, Abou-Attia, Metwally SM, Bassyouni AM, Shalaby GA.(2004). Utilization of biological control agents for controlling some sugar beet insect pests at Kafr El-Sheikh Region. Egypt. J. Biol Pest Control. 14(1): 7882 .
Mesbah, A.H. (2007). Integrated pest management on major insect pests at Kafr El Sheikh region. Egypt, J. Agric. Res., 85(6): 2027-2050.

Nehad M. E., Hassan. F. D. and El-Sayed, Y. A. (2008). Toxicicological evaluation and biochemical impacts for, Radiant SC ${ }^{-1} 12 \%$ a new generation of spinosyn on Spodoptera littoralis (Boisd.) larvae. Egypt. Acad. J. biolog. Sci., 1(2): 85 - 97.

Rossi, V. (1999). Effect of host resistance and fungicide sprays against Cercospora leaf spot in different sugar beet-growing areas of the Mediterranean basin. Phytopathologia Med., 38, 76-88

Salama R. A. K. and S. Elnagar The tortoise beetle, Cassida vittata Vill. (Col., Chrysomelidae), a possible pest of sugar beet plantations in Egyp . Journal of Applied Entomology. Volume 113, Issue 1-5, January/December 1992, Pages: 88-92

Saleh, A.Y.(1994). Insecticide test to the control of tortoise beetle, Cassida vittata (Vill) in sugarbeet crops. Assiut J.1 of Agric.l Sci. (Egypt) 197-204.

Samy, M.A.E. Draz, K.A.A El-Khawalka, M.H.M. (1993) Seasonal fluctuation of Cassida vittata L. and Pegomyia mixta (VILL.), and three predators in certain sugar beet varieties plantation at Sakha, Egypt Journal of Agricultural Sciences, Mansoura Univ13(3): 3095-3064

Zarif, G. and E,M, Hegazi (1990). Effect of nitrogen fertilization and sugarbeet cultivars on the population of Pegomyia mixta Vill (Diptera ; Anthomyidae) . Com. Sci. \& Dev. Res. 29:1;19-35 


\section{प]}

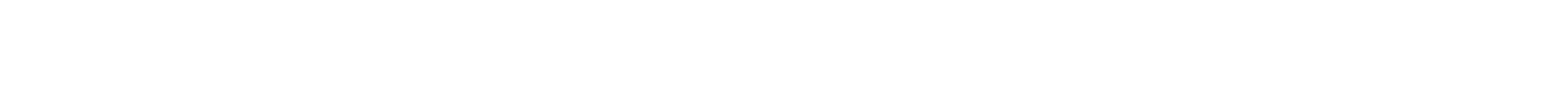

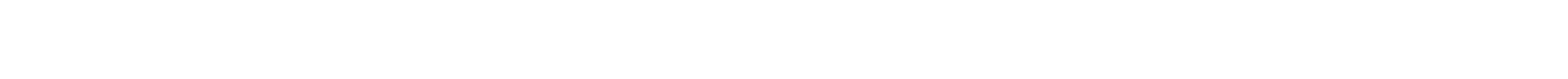

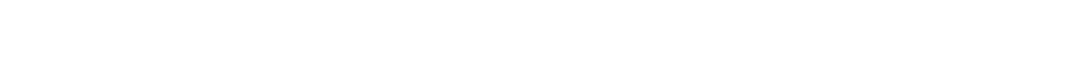

وجد ل التذبذب العددى (يرقات وهشرة كلمالة) للخفمساء

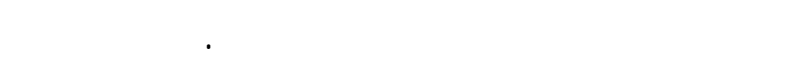

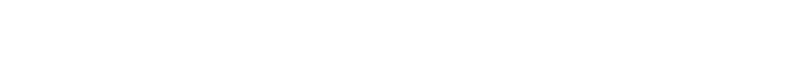
هلسنكي كل اكز مقاومة للاصابة [لنفساء البنجر السلحفائية

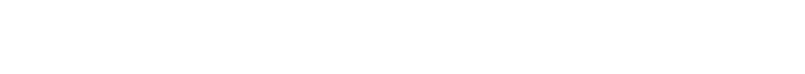

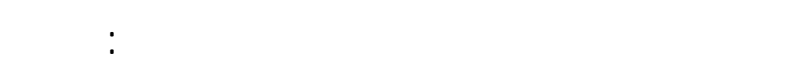

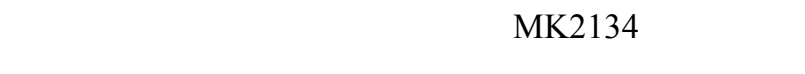

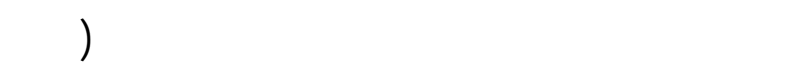

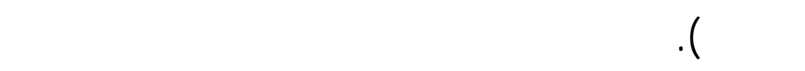

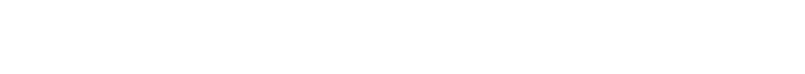

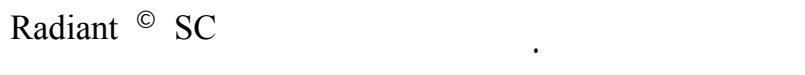

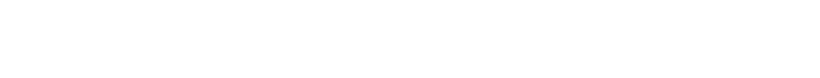

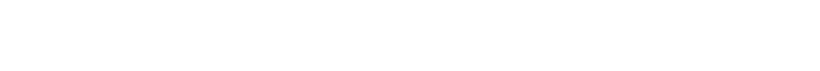

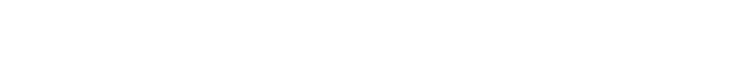

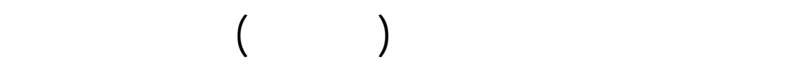

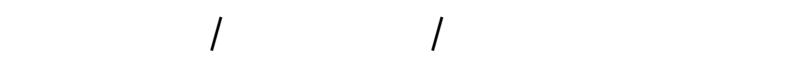

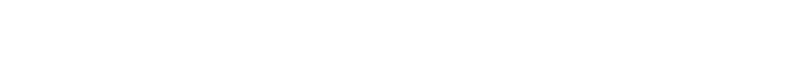

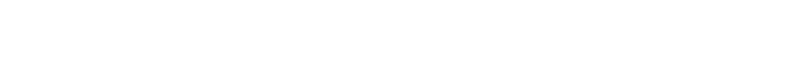

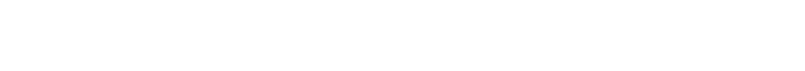
للاصابة بالتفساك السلحفائية

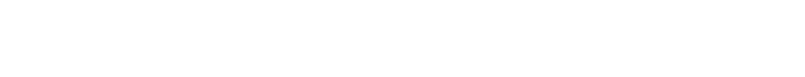

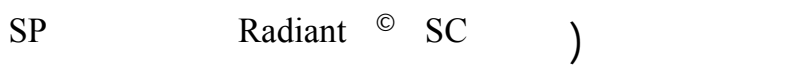
و (C) Mespilan`

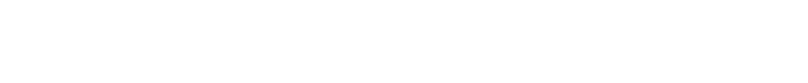
بنجر السكر. 